\title{
Electronic Word of Mouth, Destination Image, and Satisfaction toward Visit Intention: an Emperical Study in Malioboro Street, Yogyakarta
}

\author{
Rangga Restu Prayogo, Faisal Lafi Sadin Ketaren \\ Graduate School of Business Administration \\ Universitas Diponegoro \\ Semarang, Indonesia \\ ranggarestuprayogo@yahoo.com
}

\author{
Rizky Mustika Hati \\ Graduate School of Master Management \\ Universitas Padjadjaran \\ Bandung, Indonesia \\ rizky.mustika@yahoo.com
}

\begin{abstract}
Drawing on an overarching framework of marketing on tourism management. This study develops and tests an integrated model of electronic word of mouth (e-WOM), destination Image, and satisfaction toward visit intention. The model is tested using data and survey of 215 respondents. The analysis was carried out by employing Structural Equation Modeling (SEM). The data was processed with WarpPLS 3.0. The result confirm that; ewom is positively and significantly related to satisfaction, and visit intention but insignificant with destination image. On the other hand, destination image is positively and significantly related to visit intention and satisfaction are shown to have insignificant influence on visit intention. The theoretical and empirical implications of these results are discussed.
\end{abstract}

Keywords- Electronic Word of Mouth, Destination Image, Satisfaction, Visit Intention, Tourism Indonesia

\section{INTRODUCTION}

Some researchers consider consumer-to-consumer communication such as word of mouth (WOM) to be a strong and credible influence on consumer behavior. Although WOM has traditionally been studied from the perspective of face-toface communication Word of mouth (Gupta \& Harris, 2010). WOM is communication about products and services between people who are perceived to be independent of the company providing the product or service, in a medium perceived to be independent of the company and WOM is acknowledged to play a considerable role in influencing and forming consumer attitudes and behavioral intentions (Jalilvand, Ebrahimi, \& Samiei, 2013). With the spread of the Internet, virtual interactions among tourists have become common place, which has led some tourism researchers to point out that eWOM plays an important role in the acquisition and retention of tourists in the ecommerce era (Litvin, Goldsmith, \& Pan, 2008). The concept of e-WOM is a change of word of mouth which is on a limited basis as talks about products and services with the development of the times, the word of mouth turned into eWOM internet-based so it can encompass a wider audience (Sen \& Lerman, 2007).
E-WOM is an informal communication tool was directed at consumers through internet-based technologies which is relating to the usage or the particular characteristics of goods and services (Ladhari \& Michaud, 2015b). Electronic Wordof-Mouth (eWOM) is "any positive or negative statement made by potential, actual, or former customers about a product or company, which is made available to a multitude of people and institutions via the Internet (See-to \& Ho, 2014). E-WOM communicates with so many ways example, website, twitter, facebook, instagram, and platform with web-based (HennigThurau, Gwinner, Walsh, \& Gremler, 2004).

There are so many tourists are looking for sites using eWOM for more modern, fun, and easier reliable than information supplied by travel companies (Abubakar \& Ilkan, 2016). Therefore, the destination image, satisfaction, and visit intention also influenced by e-WOM of a tourist destination (Abubakar \& Ilkan, 2016). From the research e-WOM can affect the tourism destination image somewhere to visit by tourists such as research (Abubakar \& Ilkan, 2016; Setiawan, 2014). e-WOM plays an important role in creating destination image that tourists made after their vacation. E-WOM can also affect the satisfaction of tourists received when obtaining information is received for a visit to a place such as research (Setiawan, 2014; Woo, Jin, \& Sanders, 2015). E-WOM can also affect the visit intention somewhere tour (Abubakar \& Ilkan, 2016; Chen, Shang, \& Li, 2014; Jalilvand et al., 2013; Kim \& Jun, 2016; Ladhari \& Michaud, 2015a; Luo \& Zhong, 2015).

Destination image and satisfaction can also affect to visit intention tourists (Abubakar \& Ilkan, 2016; Hultman, Skarmeas, Oghazi, \& Beheshti, 2015; Reza, Ebrahimi, \& Samiei, 2013; Reza Jalilvand, Samiei, Dini, \& Yaghoubi Manzari, 2012; Shawn \& Feng, 2007; Stylos, Vassiliadis, Bellou, \& Andronikidis, 2016; Tan, 2016).

Malioboro Street is the most famous street in Yogyakarta. Located in the heart of Yogya, this is the city's main street, and was once the ceremonial avenue for the Sultan to pass through on his way to and from the Keraton. During such occasions Malioboro would be festively decorated with flowers. Some 
say that the name Malioboro" derives from the name of the British governor Marlborough from the era when Britain ruled the archipelago, between 1811-1816. The street is the centre of Yogyakarta's largest tourist district surrounded with many hotels, restaurants, and shops nearby. Sidewalks on both sides of the street are crowded with small stalls selling a variety of goods. In the evening several open-air street side restaurants, called lesehan, operate along the street. This is the street of the artists. Street musicians, painters, and other artists exhibit their creations on this road. Less obvious to the tourist, but more for the local population, side streets, lanes and structures that lead on to Malioboro are as important as the street itself (www.indonesia-tourism.com).

This paper studies : (1) the effect of e-WOM on destination image; (2) the effect of e-WOM on Satisfaction; (3) the effect of e-WOM on the visit intention of the visit intention of Malioboro street; (4) the effect of destination on visit intention of Malioboro Street; (5) the effect of Satisfaction on the visit intention of Malioboro street. The paper then outlines challenges and opportunities for the tourism industry and suggests relevant marketing strategies to manage and enhance interpersonal influence online. Finally, the study aims at building a conceptual model to empirically describe and confirm the increase in visit intention through a tourism.

\section{LITERATURE REVIEW AND CONCEPTUAL FRAMEWORK}

\section{e-WOM, Destination Image, and satisfaction}

The importance of word of mouth (WOM) in business has been widely discussed and researched, especially the worldwide adoption of Internet technology, which has revolutionized the distribution and influence of word of mouth (Jalilvand et al., 2013). e-WOM (electronic word of mouth) is defined as "any positive or negative statement made by potential, actual, or former customers about a product or company, which is made available to a multitude of people and institutions via the Internet (Woo et al., 2015). E-WOM is an informal communication tool was directed at consumers through internet-based technologies which is relating to the usage or the particular characteristics of goods and services. So with the progress of internet technology, it increases the number of tourists who use internet to search for information purposes and to conduct online transactions (Litvin et al., 2008). The easy way for tourist who are looking for information about travel destinations is the use of e-WOM (Ladhari \& Michaud, 2015a). There are so many tourists are looking for sites using e-WOM for more modern, fun, and easier reliable than information supplied by travel companies. The concept of e-WOM is a change of word of mouth which is on a limited basis as talks about products and services. With the development of the times, the word of mouth turned into eWOM internet-based so it can encompass a wider audience (Sen \& Lerman, 2007). e-WOM communicates with so many ways example, website, twitter, facebook, instagram, and platformwith web-based (Hennig-Thurau et al., 2004)

Destination image is defined as an individual's mental representation of knowledge, feelings and overall perception of a particular destination and destination image has also been found to influence tourists' behavioral intention (Assaker,
Esposito, \& Connor, 2011). Destination image is a combination of products variation, attractions, and attributes are added to the impression from selection process based on various information (Whang, Yong, \& Ko, 2016). Destination image is a person's perception of products, objects, behaviors and events that are driven by beliefs, feelings and set of goals that have ideas and hopes for a specific place or trip (Stylos et al., 2016). Destination image plays two important roles in behaviors: (1) to influence the destination choice decision-making process and (2) to condition the after-decision-making behaviors including participation (on-site experience), evaluation (satisfaction) and future behavioral intentions (intention to revisit and willingness to recommend) ( $\tilde{\mathrm{A}} \&$ Tsai, 2007).

Satisfaction is another important term that has received much attention in general consumer behavior research as well as tourism research because satisfaction brings positive behavioral outcomes and the understanding of satisfaction provides managerial guidance in the industry defined satisfaction as customer judgment about product or service fulfillment. proposed a definition that satisfaction is the outcome of the subjective evaluation about whether or not the chosen alternative meets or exceeds the expectation (Shawn \& Feng, 2007). Satisfaction has received much attention in the marketing literature. Satisfaction is defined as customers' judgments about products or service fulfillment (RamseookMunhurrun, Seebaluck, \& Naidoo, 2015).

The influence of e-WOM on destination image, satisfaction, and visit intention

e-WOM communicates with so many ways example, website, twitter, facebook, instagram, and platform with webbased (Hennig-Thurau et al., 2004). With the e-WOM can provide information that is more into details about a place that will create an image of a place to visit (Reza Jalilvand et al., 2012; Setiawan, 2014). E-WOM also plays an important role in creating destination image that tourists made after their vacation. e-WOM affects the image of destination image on tourists visiting to Turkey (Abubakar \& Ilkan, 2016). Therefore, e-WOM positively influences to destination image in Teheran, Iran (Reza Jalilvand et al., 2012).

While the influence of e-WOM toward satisfaction, (Woo et al., 2015) find that e-WOM has a positive and significant impact on satisfaction in market place. Then, (San-martín, Prodanova, \& Jiménez, 2015) find that WOM has a positive and significant impact on satisfaction. But, from the research (Setiawan, 2014) find that e-WOM has not positive and significant impact on satisfaction.

In their research, The easy way for tourist who are looking for information about travel destinations is the use of e-WOM (Ladhari \& Michaud, 2015). Visit intention emphasizes tourists to visit again in tourism context within a certain period so it can create an intention to visit (Chen et al., 2014; Ferns \& Walls, 2012; Kim \& Jun, 2016; Wisata et al., n.d.). Visit Intention also refers to the probability of what tourists feel for a certain time so it can build subjective perception that affects the behavior and the final decision (Whang et al., 2016). Intention of tourists to visit the hotel is also influenced by information which is derived from e-WOM (Ladhari \& Michaud, 2015). Then, e-WOM is very influential on helping 
tourists to find information on determining the intention of visit travel to certain places in Turkey (Abubakar \& Ilkan, 2016). Therefore, the hypotheses are as follows:

H1: e-WOM has a positive and significant effect on destination image

H2 : e-WOM has a positive and significant effect on satisfaction

H3 : e-WOM has a positive and significant effect on visit intention

The effect of destination image and satisfaction on visit intention

Destination image has greatly contributed to the visit Intention of tourists to come to the tourist attractions. The decision on the visit Intention of tourists are very influences to the destination image which is owned by a particular tourist spot in Iran (Abubakar \& Ilkan, 2016). Then, the visit intention destinations is directly influenced by the destination image which is owned by a tourist (Whang et al., 2016). Furthermore, the results is reinforced that destination image has a positive and significant effect on the tourist destinations to determine the intention of their visits to a beautiful place in Iran (Reza Jalilvand et al., 2012). With variety of earlier researchs, the destination image is an impression or expression which is obtained by a tourists on their journey. So with the image of tourist destinations may affect decision of visit those places.

In their research, (Kuo, Wu, \& Deng, 2009) find that the satisfaction has positive and significant effect on visit intention. Then, (Hultman et al., 2015) finds that satisfaction has effect on visit intention. But, research (Hultman et al., 2015; Shawn \& Feng, 2007) finds that the satisfaction has not positive and not significant effect on visit intention. Therefore, the hypotheses are:

H4 : Destination image has a positive and significant effect on visit intention

H5 : Satisfaction has a positive and significant effect on visit intention

\section{Research model}

Below is the model used in this study:

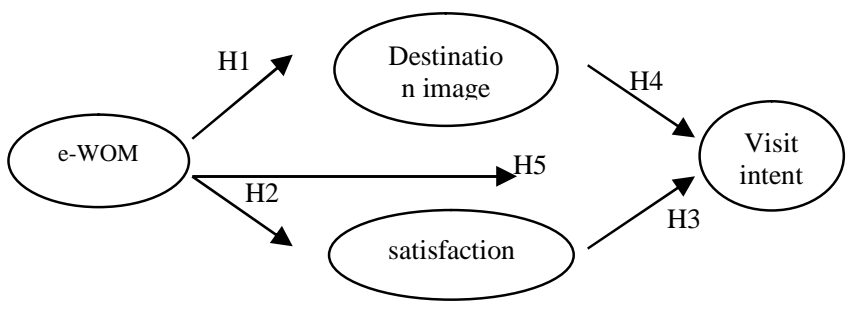

Fig. 1. Model of empirical research

Source: Model developed in this research, 2016

\section{METHODOLOGICAL APPROACH}

\section{Research design}

This study is based on a survey which was conducted between June and July 2016. The population is all tourists visit to Malioboro street. The data were collection by means of a direct survey of Malioboro street. This study uses a purposive sampling technique according to the following criteria that the respondents visit to Malioboro street. The number of respondents targeted was 250 people. Out of 250 questionnaires, 215 were completed and returned, and all of them were counted as valid. The type of questionnaire given to the respondents in this study was a closed questionnaire, inquiring about the perceptions of each respondent. The measurement used in this study is a scale of 1 to 5 (likert).

\section{Description of the respondents}

There were a total of 203 respondents, 106 of whom were male and 109 were female. Most respondent were aged between 20 and 27 years at the time of the survey. 111 respondents had bachelor's degrees, 81 respondents had high school, and 23 of them had master's degree.

TABLE I. CHARACTERISTICS OF RESPONDENTS

\begin{tabular}{llll}
\hline No & \multicolumn{1}{c}{$\begin{array}{c}\text { Characteristics of } \\
\text { respondents }\end{array}$} & Frequency & Percentage \\
\hline 1 & SEX & 106 & \\
& Male & 109 & 49,4 \\
& Female & & 50.6 \\
& Age & 15 & 6.9 \\
& $<20$ & 89 & 41.3 \\
& $20-27$ & 54 & 25.1 \\
& $28-35$ & 45 & 20.9 \\
& 36-45 & 12 & 5.8 \\
& $>45$ & & 37.8 \\
& EDUCATIONAL & 81 & 51.6 \\
& BACKGROUND & 111 & 10.6 \\
& High school & 23 & \\
& Bachelor's Degree & & \\
& Master's Degree &
\end{tabular}

Source: Primary data, 2016

\section{Operational definition of the research variables}

This study employs five main variables; e-WOM, destination image, satisfaction, and visit intention. 
TABLE II.

OPERATIONAL DEFINITION

\begin{tabular}{ll}
\hline Variables & \multicolumn{2}{c}{ Variables definition } \\
\hline e-WOM & e-WOM is defined as "any positive or \\
& negative statement made by potential, \\
& actual, or former customers about a \\
& product or company, which is made \\
& available to a multitude of people and \\
& institutions via the Internet
\end{tabular}

Source
Indicator

Woo, et al., I need information from internet before I visit 2015 intention (X1), I get a lot of tourist attractions on Malioboro street from the internet to be used as reference (X2), Before I go for travel, I always gather information from travel trip of another tourists via the internet (X3), The internet gives me a lot of benefits to choose the best tourist destination (X4)

Destination Destination image is a person's perception Stylos, et I loved and was intrigued by the history of Image of products, objects, behaviors and events that are driven by beliefs, feelings and set of goals that have ideas and hopes for a specific place or trip

Satisfaction Satisfaction is the outcome of the subjective evaluation about whether or not the chosen alternative meets or exceeds the expectation

Visit intention

Visit Intention refers to the probability of what tourists feel for a certain time so it can build subjective perception that affects the behavior and the final decision al., 2016 Feng, 2007 malioboro street (X5), Javanese culture that exists in malioboro street makes me happy (X6), Malioboro street has a beautiful view at night (X7), I feel comfortable being in malioboro street (X8)

Malioboro is place that can make me satisfied (X9), the information I received about malioboro street makes me satisfied to make a visit (X0), I make a visit to malioboro street because it has a satisfaction in seeking information from the internet (X11)

(Whang et I predict I will visit Malioboro street in the al., 2016) future (X12), I would visit Malioboro street rather than any other tourism destination(X13), If everything goes as I think, I will plan to visit Malioboro street in the future (X14)

\section{Analytical techniques}

The model used in this research is Structural Equation Modeling (SEM) with WarpPLS 3.0 statistical techniques as a tool to test the data.

\section{Validity and reliability}

In this study, reliability is measured by using composite reliability. Generally, the minimum value of the composite reliability is 0.5 (Ringle, n.d, 2014). All variables have reliability, since their respective values are shown to surpass the required value. Composite reliability of e-WOM 0.776; destination image is 0.747 ; satisfaction is 0.743 ; and visit intention is 0.749 . The are two measurements of composite validity. The first measurement is convergent validity. The minimum convergent validity requirement in this study is set at 0.5 (Ringle, n.d,2014). Table 3 shows all the indicator values are calculated at more than 0.7 . Therefore, all the indicator in this study are valid. The second measurement employed is the Average Variance Exstracted (AVE). The following are the AVE values for each variable, respectively: 0.668; 0.552; 0.595; and 0.563. the overall AVE values are calculated at above the required $(0.5)$. Therefore, all variable are confirmed as valid.
TABLE III. VALIDITY AND RELIABILITY

\begin{tabular}{|c|c|c|c|c|}
\hline Construct & Item & $\begin{array}{c}\text { Convergent } \\
\text { validity } \\
\end{array}$ & $\begin{array}{l}\text { Construct } \\
\text { reliability }\end{array}$ & AVE \\
\hline \multirow[t]{4}{*}{ Ewom } & $\mathrm{X} 1$ & 0.619 & & \\
\hline & $\mathrm{X} 2$ & 0.582 & & \\
\hline & $\mathrm{X} 3$ & 0.727 & 0.776 & 0.668 \\
\hline & $\mathrm{X} 4$ & 0.787 & & \\
\hline Destination & X5 & 0.701 & & \\
\hline \multirow[t]{3}{*}{ Image } & X6 & 0.390 & 0.747 & 0.738 \\
\hline & $\mathrm{X} 7$ & 0.706 & & \\
\hline & $\mathrm{X} 8$ & 0.780 & & \\
\hline \multirow[t]{3}{*}{ Satisfaction } & X9 & 0.774 & & \\
\hline & $\mathrm{X} 10$ & 0.580 & 0.743 & 0.595 \\
\hline & X11 & 0.741 & & \\
\hline \multirow[t]{3}{*}{ Visit intention } & $\mathrm{X} 12$ & 0.777 & & \\
\hline & $\mathrm{X} 13$ & 0.782 & 0.794 & 0.563 \\
\hline & $\mathrm{X} 14$ & 0.689 & & \\
\hline
\end{tabular}

Source : Primary data, 2016

\section{RESULT}

This study has shown a very good model fit $(\mathrm{APC}=0.278$; $\mathrm{ARS}=0.171 ; \mathrm{AVIF}=1.269)$. The test results show that hypotheses $\mathrm{H} 2, \mathrm{H} 3$, and $\mathrm{H} 4$ are supported. The e-WOM variable has positive and significant effect on satisfaction, eWOM has positive and significant effect on visit intention, and destination image has positive and significant effect on visit intention.on the other hand, $\mathrm{H} 1$ and $\mathrm{H} 5$ indicate that this effect has proven to be insignificant. E-WOM does not have a significant effect on destination image, and satisfaction does not a significant effect on visit intention. See the result of the 
hypothesis testing in table 4 and the path diagram in the figure 2.

\section{DISCUSSION AND ANALYSIS}

\section{Effect of e-WOM on Destination Image}

This study finds that the relation between e-WOM and destination image positively but insignificant. Witch mean that hypothesis $\mathrm{H1}$ has been rejected (Table 5). These result are not in line with the opinion of previous researchers (Abubakar \& Ilkan, 2016; Reza et al., 2013; Setiawan, 2014). Some of the experts did not directly examine destination image. However, the relationship between e-WOM and destination image can be generalized in various fields which are studied. This can be explained from the fact that there is e-WOM on information Malioboro street which directly effect destination image.

TABLE IV. RESULS OF HYPOTHESIS TESTING

\begin{tabular}{lllll}
\hline & \multicolumn{2}{c}{ Proposed effect } & \multicolumn{1}{c}{$\begin{array}{c}\text { Path } \\
\text { coefficient }\end{array}$} & Result \\
\hline H1 & $\begin{array}{l}\text { e-WOM } \rightarrow \quad \text { Destination } \\
\text { Image }\end{array}$ & 0.102 & Insignificant \\
H2 & $\begin{array}{l}\text { e-WOM } \rightarrow \text { Satisfaction } \\
\text { H3 }\end{array}$ & $\begin{array}{l}\text { e-WOM } \rightarrow \text { Visit Intention } \\
\text { Destination Image } \rightarrow \text { Visit } \\
\text { H4 }\end{array}$ & 0.376 & $\begin{array}{l}\text { Significant } \\
\text { Intention } \\
\text { Satisfaction }\end{array} \quad \rightarrow \quad$ Visit \\
Intention
\end{tabular}

Source: Primary data, 2016

\section{Effect of e-WOM on Satisfaction}

The finding in this study show that e-WOM has a positive and significant impact on satisfaction, which mean that hypothesis $\mathrm{H} 2$ has been proven (Table 5). This also reinforces that belief of (Litvin et al., 2008) about e-WOM being seen as a driving factor to give information tourist satisfaction. Tourist satisfaction is derivert from the e-WOM about Malioboro Street. Tourist are satisfied because more information about Malioboro Street in the internet.

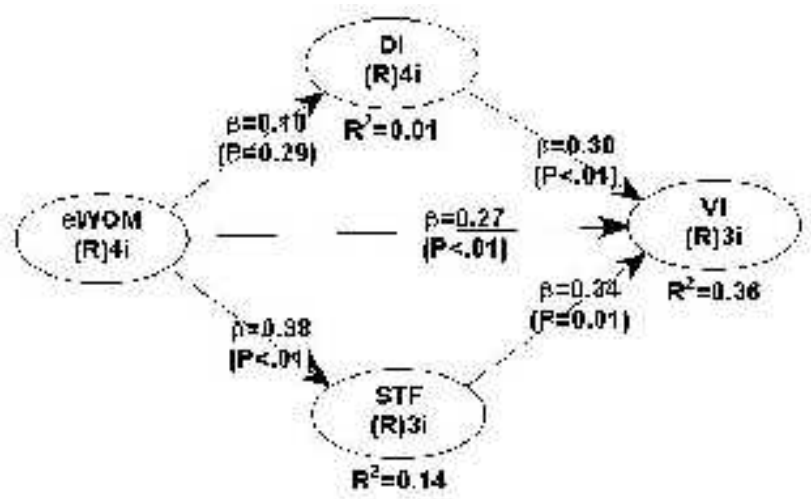

Fig. 2. Path Diagram

Legend :*sign $<0.05$

Source : Model developed in this research, 2016

\section{Effect of e-WOM on Visit intention}

Positive e-WOM also has a positive and significant effect on visit intention, which means that hypothesis $\mathrm{H} 3$ has been proven (Table 5). This also reinforces that belief of (Setiawan, 2014; Student \& Juni, n.d.2014). This may imply that when tourist come to some place they need information to visit.

\section{Effect of Destination Image on Visit intention}

Positive destination image has a positive and significant effent on visit intention, which means that Hypothesis $\mathrm{H} 4$ has been proven (Table 5). These result are line with the opinion of previous researchers ( $\tilde{A}$ \& Tsai, 2007; Ferns \& Walls, 2012; Ramseook-Munhurrun et al., 2015; Tan, 2016). This finding indicates that before tourist want to go some where, may the are see cognitive image, affective image and conative image in some place and they are visit intention.

\section{Effect of Satisfaction on Visit intention}

Satisfaction positively but not significantly influences visit intention. There for, hypothesis H5 was rejected (Table 5). This result are not in line with the opinion of previous researchers (Hultman et al., 2015). Some of the experts did not directly examine satisfaction. However the relationship between satisfaction and visit intention can be generalized in various fields or studied.

\section{CONCLUSIONS AND MANAGERIAL IMPLICATION}

From the analyzed driving factors, it can be concluded that (H1) e-WOM does not have a significant effect on destination image, (H2) e-WOM has a positive and significant effect on satisfaction, (H3) e-WOM has a positive and significant effect on visit intention, (H4) destination image has a positive and significant effect on visit intention, (H5)) satisfaction does not have a significant effect on visit intention. Therefore, the results of this research show that e-WOM insignificant on destination image. This is because message/value it brings is not effective for creating image someplace. Then, satisfaction have not a significant on visit intention because discrepancy information sought about a place.

The managerial implication of this research is that it can directly influence the behavior of tourism Indonesia. This research provide input that information over the internet (eWOM) very function is to attract tourists and to visit tourist destinations in Indonesia. Then, the image of the destinations must be constantly improved for the sustainability of tourism in Indonesia.

\section{REFERENCES}

Ã, C. C., \& Tsai, D. (2007). How destination image and evaluative factors affect behavioral intentions?, 28, 1115-1122. http://doi.org/10.1016/j.tourman.2006.07.007

Abubakar, A. M., \& Ilkan, M. (2016). Impact of online WOM on destination trust and intention to travel: A medical tourism perspective. Journal of Destination Marketing \& Management, $1-10$. 
Assaker, G., Esposito, V., \& Connor, P. O. (2011). Examining the effect of novelty seeking, satisfaction, and destination image on tourists 'return pattern: A two factor , non-linear latent growth model. Tourism Management, 32(4), 890-901. http://doi.org/10.1016/j.tourman.2010.08.004

Chen, Y. C., Shang, R. A., \& Li, M. J. (2014). The effects of perceived relevance of travel blogs' content on the behavioral intention to visit a tourist destination. Computers in Human Behavior, 30, 787-799. http://doi.org/10.1016/j.chb.2013.05.019

Ferns, B. H., \& Walls, A. (2012). Enduring travel involvement, destination brand equity, and travelers' visit intentions: A structural model analysis. Journal of Destination Marketing and Management, 1(1-2), 27-35. http://doi.org/10.1016/j.jdmm.2012.07.002

Gupta, P., \& Harris, J. (2010). How e-WOM recommendations in $\mathrm{fl}$ uence product consideration and quality of choice: A motivation to process information perspective. Journal of Business Research, 63(9-10), 1041-1049. http://doi.org/10.1016/j.jbusres.2009.01.015

Hennig-Thurau, T., Gwinner, K. P., Walsh, G., \& Gremler, D. D. (2004). Electronic word-of-mouth via consumeropinion platforms: What motivates consumers to articulate themselves on the Internet? Journal of Interactive Marketing, 18(1), 38-52. http://doi.org/10.1002/dir.10073

Hultman, M., Skarmeas, D., Oghazi, P., \& Beheshti, H. M. (2015). Achieving tourist loyalty through destination personality, satisfaction, and identi fi cation. Journal of Business Research, 68(11), 2227-2231. http://doi.org/10.1016/j.jbusres.2015.06.002

Jalilvand, M. R., Ebrahimi, A., \& Samiei, N. (2013). Electronic Word of Mouth Effects on Tourists' Attitudes Toward Islamic Destinations and Travel Intention: An Empirical Study in Iran. Procedia - Social and Behavioral Sciences, 81(2006), 484-489. http://doi.org/10.1016/j.sbspro.2013.06.465

Kim, S., \& Jun, J. (2016). The impact of event advertising on attitudes and visit intentions. Journal of Hospitality and Tourism Management, 29, 1-8. http://doi.org/10.1016/j.jhtm.2016.04.002

Kuo, Y. F., Wu, C. M., \& Deng, W. J. (2009). The relationships among service quality, perceived value, customer satisfaction, and post-purchase intention in mobile value-added services. Computers in Human Behavior, 25(4), 887-896. http://doi.org/10.1016/j.chb.2009.03.003

Ladhari, R., \& Michaud, M. (2015a). EWOM effects on hotel booking intentions, attitudes, trust, and website perceptions. International Journal of Hospitality Management, $\quad 46, \quad 36-45$. http://doi.org/10.1016/j.ijhm.2015.01.010

Ladhari, R., \& Michaud, M. (2015b). International Journal of Hospitality Management eWOM effects on hotel booking intentions, attitudes, trust, and website perceptions. International Journal of Hospitality
Management,

46 ,

http://doi.org/10.1016/j.ijhm.2015.01.010

$36-45$.

Litvin, S. W., Goldsmith, R. E., \& Pan, B. (2008). Electronic word-of-mouth in hospitality and tourism management. Tourism Management, 29(3), 458-468. http://doi.org/10.1016/j.tourman.2007.05.011

Luo, Q., \& Zhong, D. (2015). Using social network analysis to explain communication characteristics of travel-related electronic word-of-mouth on social networking sites. Tourism Management, 46, 274-282. http://doi.org/10.1016/j.tourman.2014.07.007

Ramseook-Munhurrun, P., Seebaluck, V. N., \& Naidoo, P. (2015). Examining the Structural Relationships of Destination Image, Perceived Value, Tourist Satisfaction and Loyalty: Case of Mauritius. Procedia - Social and Behavioral Sciences, 175(230), 252-259. http://doi.org/10.1016/j.sbspro.2015.01.1198

Reza, M., Ebrahimi, A., \& Samiei, N. (2013). Toward Islamic Destinations and Travel Intention: an Empirical Study in. Procedia - Social and Behavioral Sciences, 81(2006), 484-489. http://doi.org/10.1016/j.sbspro.2013.06.465

Reza Jalilvand, M., Samiei, N., Dini, B., \& Yaghoubi Manzari, P. (2012). Examining the structural relationships of electronic word of mouth, destination image, tourist attitude toward destination and travel intention: An integrated approach. Journal of Destination Marketing and Management, 1(1-2), 134-143. http://doi.org/10.1016/j.jdmm.2012.10.001

Ringle, C. M. (n.d.). PARTIAL LEAST SQUARES STRUCTURAL EQUATION MODELING ( PLS-SEM ).

San-martín, S., Prodanova, J., \& Jiménez, N. (2015). Journal of Retailing and Consumer Services The impact of age in the generation of satisfaction and WOM in mobile shopping. Journal of Retailing and Consumer Services, 23, 1-8. http://doi.org/10.1016/j.jretconser.2014.11.001

See-to, E. W. K., \& Ho, K. K. W. (2014). Computers in Human Behavior Value co-creation and purchase intention in social network sites: The role of electronic Word-of-Mouth and trust - A theoretical analysis. Computers in Human Behavior, 31, 182-189. http://doi.org/10.1016/j.chb.2013.10.013

Sen, S., \& Lerman, D. (2007). Why are you telling me this? An examination into negative consumer reviews on the web. Journal of Interactive Marketing, 21(4), 76-94. http://doi.org/10.1002/dir.20090

Setiawan, P. Y. (2014). The Effect of e-WOM on Destination Image , Satisfaction and Loyalty, 3(1), 22-29.

Shawn, S., \& Feng, R. (2007). Temporal destination revisit intention: The effects of novelty seeking and satisfaction, 28, 580-590. http://doi.org/10.1016/j.tourman.2006.04.024

Student, B., \& Juni, D. (n.d.). The effect of different motives to positive / negative eWOM on the expectations of a webcare response and service encounter satisfaction.

Stylos, N., Vassiliadis, C. A., Bellou, V., \& Andronikidis, A. (2016). Destination images, holistic images and personal normative beliefs: Predictors of intention to revisit a 
destination. Tourism Management, 53, 40-60. http://doi.org/10.1016/j.tourman.2015.09.006

Tan, W. (2016). Journal of Destination Marketing \& Management Repeat visitation: A study from the perspective of leisure constraint, tourist experience , destination images, and experiential familiarity. Journal of Destination Marketing \& Management, (2013), 1-10. http://doi.org/10.1016/j.jdmm.2016.04.003

Whang, H., Yong, S., \& Ko, E. (2016). Pop culture, destination images, and visit intentions: Theory and research on travel motivations of Chinese and Russian tourists. Journal of Business Research, 69(2), 631-641. http://doi.org/10.1016/j.jbusres.2015.06.020

Wisata, K. D., Dan, K., Kunjungan, N., Wisatawan, K., Di,
M., Tengah, J., ... Stikubank, U. (n.d.). Kualitas dayatarik wisata, kepuasan dan niat kunjungan kembali wisatawan mancanegara di jawa tengah.

Woo, C., Jin, Y., \& Sanders, G. L. (2015). Information \& Management The impact of interactivity of electronic word of mouth systems and E-Quality on decision support in the context of the e-marketplace. Information \& Management, 52(4), 496-505. http://doi.org/10.1016/j.im.2015.03.001

\section{Website}

http://www.indonesiatourism.com/forum/showthread.php?1471-Malioborostreet-Yogyakarta 